\title{
Uncertainty in International Crises
}

\author{
Muhammet Bas, Elena McLean, and Taehee Whang
}

This study focuses on sources of uncertainty in two substantive areas of international security: militarized disputes and economic sanctions. We revisit realist and liberal debates as two long-standing paradigmatic approaches that address the role of uncertainty, and draw on their insights to identify key variables that represent sources of uncertainty. We evaluate these variables' effects on uncertainty using a heteroskedastic probit model and data on disputes and sanctions. We find that measures of power parity, system multipolarity, joint democracy and trade are significantly linked to levels of uncertainty for disputes and military conflict. For sanctions, only realist variables affect uncertainty levels. We also find some evidence of a substitution effect suggesting that factors that increase the likelihood of military conflict and the amount of uncertainty about military options tend to have the opposite effect when it comes to sanctions.

Key Words: uncertainty, realism, liberalism, military disputes, economic sanctions, Heteroskedastic probit

$\mathrm{F}$ ew concepts have been as central to the study of international relations as the concept of uncertainty. In Thucydides' History of the Peloponnesian

*Muhammet A. Bas(mbas@gov.harvard.edu) is associate professor of Government at Harvard University. He received his Ph.D. from the University of Rochester. His research is on international conflict, uncertainty, and nuclear proliferation. His work has appeared in International Organization, Political Analysis, International Studies Quarterly, and Journal of Conflict Resolution.

**Elena V. McLean(elenamcl@buffalo.edu) is associate professor of Political Science at the State University of New York at Buffalo. She received her Ph.D. from the University of Rochester. Her areas of specialization include international institutions and economic sanctions. Her recent research has been published in International Organization, American Journal of Political Science, and Journal of Politics.

***Taehee Whang(thwhang@yonsei.ac.kr) is associate professor and Chair of Political Science and International Studies at Yosei Univeirstiy. He received his Ph.D. from the University of Rochester. His research interest includes economic sanctions and aid, international relations, political methodology, and politics and economy of North Korea. His works appear in American Journal of Political Science, International Interactions, International Organization, International Studies Quarterly, Political Analysis, Journal of Peace Research, and Journal of Theoretical Politics.

This work was supported by the Ministry of Education of the Republic of Korea and the National Research Foundation of Korea (NRF-2016S1A3A2925085). The authors are listed in alphabetical order and have made equal contributions. 
War, Brasidas, a Spartan officer, highlights effects of uncertainty on decisionmaking in a crisis: "Where an enemy seems strong but is really weak, a true knowledge of the facts makes his adversary the bolder, just as a serious antagonist is encountered most confidently by those who do not know him."1 Uncertainty's relevance goes beyond interstate crises: it shapes decisionmaking and interactions in areas such as security, economic cooperation, and international institutions. A significant body of existing research that focuses on this concept and identifies different types of uncertainty, their relevant sources, and their effects on actor behavior in international relations further underscores its importance.

While there has been progress on both the theoretical and empirical fronts, theoretical literature is especially vast on this topic. Scholars have employed game theoretical, psychological and behavioral approaches to study effects of uncertainty on decision-making processes and foreign policy choices. A theoretical starting point is to acknowledge that uncertainty can take many different forms. Bas and Schub (2017b), for instance, identify three different types of uncertainty relevant to international conflict: (i) uncertainty about war related payoffs, including military capabilities (Wagner 1994; Smith and Stam 2004), cost of war (Fearon 1995; Schultz 1999) and military effectiveness (Arena 2013); (ii) uncertainty about adversaries' preferences and intentions in crises, in particular with regard to trust (Kydd 2005), war aims (Spaniel and Bils 2016), and intentions (Jervis 1976; Kydd 1997); and finally (iii) fundamental sources of uncertainty, such as uncertainty about war outcomes (Bas and Schub 2016a) and long term power shifts (Bas and Schub 2017a), among others. This list can be easily expanded. Depending on its type, uncertainty can be a source of peace or conflict. For instance, according to standard accounts of conflict, asymmetric information about resolve or capabilities and incentives to misrepresent can make wars more likely (Fearon 1995). At the same time, some studies indicate that reducing uncertainty through greater intelligence can also increase the risk of conflict (Arena and Wolford 2012), while uncertainty about the magnitude and duration of power shifts can induce peace (Bas and Schub 2017).

Similarly, empirical studies acknowledge various types of uncertainty and offer alternative ways of measuring it. Uncertainty in the form of private information, by definition, is very difficult to measure directly. Instead, scholars often use proxies to account for it: specifically, relative capabilities capture the amount of uncertainty in a dyad, with balanced dyads representing a more uncertain environment (Reed 2003); secret alliances serve as a source of states' private

\footnotetext{
${ }^{1}$ Thucydides, The History of the Peloponnesian War, The Fourth Book, Chapter XIV.
} 
information about their capabilities, thereby reflecting the existence of mutual optimism (Bas and Schub 2016b); some regime types may enable states to signal their resolve, which would indicate reduced uncertainty levels in crises (Schultz 1998). In addition, scholars have developed methodological techniques appropriate for gauging the amount of uncertainty about present or future preferences in strategic models (Bas 2012; Bas, Signorino, and Whang 2014).

The main goal of this article is to build on the existing empirical literature to identify sources of uncertainty in two important substantive areas: interstate disputes and conflict; and the threat and imposition of economic sanctions. As our brief literature overview suggests, research on the role of uncertainty has been limited to militarized disputes, while the influence of uncertainty on other policy options, such as economic sanctions, has been largely overlooked. Sanctions, in particular, have become an increasingly popular foreign policy instrument in recent decades. Some policy makers and scholars have proposed that economic sanctions are a nonviolent policy option, allowing states to address international crises without resorting to the use of costly military force (Helms 1999). Sanctions, consequently, are seen as a policy option falling between diplomatic words and wars (Selden 1999). The inclusion of nonmilitary policy tools in the analysis of uncertainty is particularly important in the light of substantial empirical evidence supporting the democratic peace theory: if democracies do not fight, they must use other policy tools in international crises, and economic sanctions may serve as such a tool (HafnerBurton and Montgomery 2008b). If these arguments are correct, the use of force and imposition of sanctions can be viewed as policy substitutes. When military options are perceived to be costly or uncertain, states might opt for sanctions instead. In the context of uncertainty, factors that affect the amount of uncertainty for a given choice might have the opposite effects for its policy substitute. Hence, we seek to extend the study of uncertainty by developing a unified approach to incorporate both military and non-military policy options, which allows us to test the policy substitution argument.

With respect to sources of uncertainty, our analyses tap into two long-standing paradigmatic debates in international relations about the role of uncertainty. On the one hand, neo-realist scholars emphasize structural constraints that shape state behavior, and like earlier realist approaches that neo-realists build upon, assign critical importance to military power in interstate relations. ${ }^{2}$ From

\footnotetext{
${ }^{2}$ We are cognizant of the significant differences across realist and neo-realist schools in terms of the role of uncertainty in international relations, and their emphasis on state capabilities and their distribution. We group them together and henceforth refer to realists and neo-realists simply as 're-
} 
this perspective, states' relative capabilities, their distribution in a dyad or in the international system, as well as their changes over time are relevant for the amount of uncertainty in interactions, and provide other states with information about their opponents. Liberal and neoliberal scholars, on the other hand, point out that there are additional mechanisms that states can use to accumulate information about others and transmit information about themselves to other states. ${ }^{3}$ In particular, democratic political institutions, commercial ties, and joint membership in international organizations (IOs) can help reduce uncertainty levels between states. In our analyses, the variables that we employ will help differentiate which factors, realist or liberal, are more relevant for uncertainty levels.

Based on the realist and liberal approaches, we analyze effects of dyadic military balance, power shifts, the systemic distribution of power, regime type, trade relations, and IO membership on the amount of uncertainty. Overall, we find that variables associated with both schools of thought are significantly linked to amounts of uncertainty in the case of militarized disputes. For sanctions, only realist variables have a significant relationship with uncertainty levels. We also find evidence of a substitution effect, in the sense that many factors that increase the likelihood of military conflict and the amount of uncertainty about military options tend to have the opposite effects when it comes to economic sanctions.

The remainder of the article proceeds as follows. The subsequent section establishes a theoretical framework that identifies factors influencing uncertainty, and specifies their effects on uncertainty levels, as well as the likelihood of international dispute onset. We also discuss expected differences in uncertainty between military conflict and economic sanctions. We then outline our empirical approach to studying uncertainty and describe our data. Finally, we report and discuss our results, and conclude by considering implications of our findings for the study of international disputes, economic sanctions, and foreign policy making, more broadly.

\section{DETERMINANTS OF UNCERTAINTY IN INTERNATIONAL CRISES}

alists' due to our focus on their shared ideas.

${ }^{3}$ Similarly, despite a number of differences in these schools of thought, henceforth, we refer to liberal and neo-liberal scholars as 'liberals' due to the similarity in their approach to the role of uncertainty. 
Whatever its source, uncertainty has profound effects on the likelihood of conflict in interstate relations (Waltz 1979; Mearsheimer 1994; Grieco 1988). Not surprisingly, existing international conflict research has devoted a significant amount of attention to factors that reduce (or increase) uncertainty and their effects on states' willingness to engage in disputes. Our theoretical framework will focus on two classes of factors that have been identified as determinants of uncertainty and conflict propensity. The first set of factors broadly relates to states' military capabilities, their distribution, and their shift over time - these are central to realist approaches to the study of international relations. We then turn to factors such as regime type, international institutions, and trade, which realist scholars tend to downplay; yet, these factors are at the core of liberal analyses.

Distribution of power, both at the systemic and dyadic levels, is linked to uncertainty levels. First, at the systemic level, multipolar systems are more uncertain than bipolar systems due to a larger number of powerful states whose behavior must be accounted for in crises, more complex alliance arrangements, and resulting unpredictability of conflict outcomes (Waltz 1979; Christensen and Snyder 1990). ${ }^{4}$ Second, at the dyadic level, parity implies that both states have a realistic chance of winning a war, and outcomes tend to be more uncertain and harder to predict (Bas and Schub 2016a). We can operationalize systemic power distribution as the number of great powers in the system, and the distribution of power at the dyadic level as the dyadic balance of military capabilities. Thus, we test the following two hypotheses:

Hypothesis M1: Greater equality in the distribution of capabilities at the dyadic level increases uncertainty in interstate militarized disputes.

Hypothesis M2: A larger number of major powers in the international system increases uncertainty in interstate militarized disputes.

Beyond its effect on uncertainty, distribution of power also has implications for the overall likelihood of conflict. Existing studies debate whether or not this effect is pacifying. On the one hand, due to increased uncertainty, dyads at parity could be more peaceful as such uncertainty breeds caution by states

4 There are other realist arguments regarding the effect of system polarity on dispute propensity. For example, Morgenthau argues that militarized conflicts are less likely in a multipolar system than a bipolar system because uncertainty generated by multipolarity can breed caution among great powers. In this article, however, we mainly focus on Waltz's claim on system polarity. We thank an anonymous reviewer for pointing out this distinction. 
(Waltz 1959). On the other hand, when capabilities are similar, this increases the likelihood of mutual optimism emerging, which results in a greater risk of war (Blainey 1988; Bas and Schub 2016b). Some scholars also argue that we cannot predict the effect of power balance on conflict, without also knowing if it parallels the status quo distribution of benefits or not (Powell 1999). Our empirical analyses will investigate which of these approaches are supported by empirical evidence.

A second important characteristic of power is how its distribution changes over time. According to the power transition theory, the probability of conflict between states in the international system increases near the capability parity point, specifically when a rising power reaches and is about to surpass the dominant state in the system in terms of capabilities (Organski 1980). When the difference in capabilities is too large, neither state has an incentive to attack: one is not sufficiently powerful to mount a successful attack, while the other does not need to use its military power in disputes as it already dominates the system. As the capabilities change towards the parity point, however, conflict becomes a viable option, as both the dominant and challenging states have realistic chances of winning a war. In other words, the outcome is harder to predict, and uncertainty increases. As the system moves closer to parity, it becomes more conflict-prone because one of the states may have incentives to initiate military action: either the state whose power is rising will seek to defeat the dominant state and change the status quo in its favor, or the dominant state will attempt to prevent the rising power's challenge to its position. Therefore, scholars of power transition generally agree that power shifts increase the likelihood of war (Organski 1968; Gilpin 1983). The following hypothesis reflects the anticipated effect on levels of uncertainty:

Hypothesis M3: Uncertainty increases in interstate militarized disputes as states approach capability parity.

We now turn to the factors that tend to be omitted by realist approaches in studying sources of uncertainty and conflict. These are factors emphasized by the liberal school of thought. We can trace the origins of this vast literature back to Kant's discussion of conditions for peace among nations in his essay, "Perpetual Peace." The main insights of this literature represent three legs of the Kantian tripod: democratic political institutions, international economic relations, and membership in international organizations that work together as pacifying forces in international relations. Oneal and Russett (1999) summarize 
key findings from these studies: “... analyses for the years 1885 to 1992 indicate that Kant was substantially correct: democracy, economic interdependence, and involvement in international organizations reduce the incidence of militarized interstate disputes" (Ibid., 34). In addition to identifying the negative effect of these three factors on conflict likelihood, scholars have demonstrated how these factors reduce uncertainty in interstate relations. Specifically, democratic institutions, economic ties, and joint IO membership create incentives and provide opportunities for actors to share information and learn about other states, as well as enhance the credibility of existing information sharing mechanisms.

These insights generated by liberal international relations theories stem from their focus on diverse interests of actors within or beyond the state and their investigation of interactions among these various actors. This, in turn, expands the scope of uncertainty in international crises and the range of factors contributing to uncertainty levels. For example, a number of studies that seek to explain why democracies rarely fight each other focus on the extent to which policymakers and ordinary citizens of a given state share conflict costs. Moreover, these shared costs represent the idea of how easily citizens or voters (in democratic states) can remove policymakers from office. The policymakers view costs associated with representation, accountability, as well as audience costs, as important constraints when they decide to fight another state. Consequently, information regarding these constraints becomes important in the context of interstate disputes.

Now turning to one prominent strand of liberal international relations research, we consider insights from the democratic peace theory. The empirical observation that democratic dyads rarely, if ever, experience militarized conflict, has been attributed to the information-enhancing effect of democratic regimes (Schultz 1998). By credibly revealing governments' private information, democratic political institutions reduce uncertainty and lower the likelihood of interstate disputes that stem from asymmetries of information. Scholars have investigated the effect of "audience costs" that allow democracies to signal resolve more effectively, thereby reducing uncertainty and conflict (Fearon 1994; Schultz 1999). Democratic leaders, who are accountable to their voters, face significant costs in the case of failure to follow up on their previous threats; therefore, threats issued by democracies should serve as more credible signals of resolve than those issued by autocracies. As a result, uncertainty should decline, and a democratic state's opponent should be less likely to resist, thereby reducing the likelihood of militarized conflict. In addition, democracies are more transparent in their decision-making, which should further reduce uncertainty, 
since other states can more easily gauge democracies' intentions and capabilities (Schultz 1999; Ikenberry 2001). Thus, we test the following hypothesis linking regime type to uncertainty levels in international crises:

Hypothesis M4: Joint democracy decreases uncertainty in interstate militarized disputes.

A related set of studies developed the idea of commercial peace and presented empirical evidence that international economic interactions (or economic interdependence) are associated with reduced likelihood of war among states. Gartzke (2007), for instance, argues that a reduced tendency to engage in military conflict should be attributed to capitalism and common interstate interests. The pacifying effect of cross-border economic linkages is due to the fact that markets serve as mechanisms for revealing information (Gartzke, Li, and Boehmer 2001). A state's aggressive actions against its trade partner are costly because such actions generate market consequences, and the state's opponents can gain information about its resolve from observing the state's response to these economic costs. Reed (2003) suggests that trade decreases the probability of militarized conflict because "it serves to minimize distortion about the willingness of a target to give in to any specific demand issued by a dissatisfied challenger" (Ibid., 55). Two causal mechanisms generate this pacific effect of trade: trade links increase conflict costs for trading states; and trade relations provide trading states with more accurate information about each other's conflict costs. In sum, greater bilateral trade flows should mitigate uncertainty and result in a lower risk of interstate conflict.

Hypothesis M5: Trade links decrease uncertainty in interstate militarized disputes.

The third element of the Kantian peace framework - joint membership in IOs - has also been extensively evaluated in the existing research on international disputes. IOs help to reduce uncertainty among states through the following mechanisms. First, states interact within IOs repeatedly, and this allows states to demonstrate their cooperative intentions. Great powers, in particular, can use IOs to tie their hands in order to signal their intentions (Ikenberry 2001; Voeten 2005). Repeated interactions also foster expectations of reciprocity and reduce cheating by detecting non-cooperative behavior and providing information about states' compliance (Weber 1997; Abbott and Snidal 1998; Moravcsik 1999; 2000; Fortna 2003). Second, states often engage in linkage politics through IOs, 
thereby strengthening reciprocal behavior and increasing cooperative incentives. IOs also tend to increase the credibility of information shared by states (Keohane and Martin 1995; Martin and Simmons 1998). As a result, states participating in IOs have less uncertainty about others' intentions (Axelrod 1981; Keohane 1984). Lower uncertainty among member states, then, is expected to reduce incentives for conflict (Fearon 1995). Uncertainty is alleviated because IO members have opportunities for regular interactions with each other, even though outside of the IO member states may have low levels of direct communication. At the same time, Boehmer et al. (2004) argue that IOs may not always reduce the likelihood of militarized conflict: uncertainty and the probability of conflict decline only if IOs are highly institutionalized and have a security mandate, whereas IOs' failure to punish non-cooperative behavior may increase uncertainty and add to the probability of militarized conflict.

Hypothesis M6: Joint membership in international organizations decreases uncertainty in interstate militarized disputes.

In contrast to studies of military conflicts, research on economic sanctions does not offer clear predictions regarding effects of realist and liberal variables on uncertainty. Therefore, these factors may or may not affect uncertainty in similar ways in sanction episodes as in the case of militarized disputes. We argue that the influence of these factors on uncertainty depends on the motivation for choosing sanctions as a coercive policy. If sanctions and military options are used as complements, we would expect liberal and realist variables to have the same effect on uncertainty in the case of sanctions as in the case of militarized conflicts. Since a government decides to use the two coercive instruments jointly to pursue a foreign policy goal, there is no theoretical reason to anticipate differential effects. Thus, we can formulate a set of hypotheses linking liberal and realist factors to uncertainty levels to parallel our hypotheses for militarized disputes, based on the assumption that the two coercive options work as complements.

Hypothesis SC1: Greater equality in the distribution of capabilities at the dyadic level increases uncertainty in sanction episodes.

Hypothesis SC2: A larger number of major powers in the international system increases uncertainty in in sanction episodes.

Hypothesis SC3: Uncertainty increases in sanction episodes as states approach capability parity.

Hypothesis SC4: Joint democracy decreases uncertainty in sanction 
episodes.

Hypothesis SC5: Trade links decrease uncertainty in sanction episodes.

Hypothesis SC6: Joint membership in international organizations decreases uncertainty in sanction episodes.

Another possibility is that states use sanctions as substitutes for military options. In this case, realist and liberal variables should affect uncertainty in sanction episodes and militarized disputes differently. States may have an incentive to favor sanctions as a coercive instrument when military options are simply too costly and, hence, not feasible politically. Using military force can be particularly risky for policy makers in democratic states, unless there is a significant security threat. It is not surprising, therefore, that sanctioning states are mostly democracies: when opponents pursue objectionable policies, democratic states may be restricted in their use of military options and view sanctions as an acceptable alternative that is not as costly. ${ }^{5}$ In this case, determinants of uncertainty will have the opposite effect during sanction episodes compared to militarized disputes. If economic sanctions and military force are policy substitutes, then we might find that, for example, equal distribution of military capabilities or a larger number of major powers decrease uncertainty and, as a result, states are more likely to use sanctions.

Hypothesis SS1: Greater equality in the distribution of capabilities at the dyadic level decreases uncertainty in sanction episodes.

Hypothesis SS2: A larger number of major powers in the international system decreases uncertainty in sanction episodes.

Hypothesis SS3: Uncertainty decreases in sanction episodes as states approach capability parity.

Hypothesis SS4: Joint democracy increases uncertainty in sanction episodes. Hypothesis SS5: Trade links increase uncertainty in sanction episodes.

Hypothesis SS6: Joint membership in international organizations increases uncertainty in sanction episodes.

${ }^{5}$ Democratic policy-makers are also more likely to experience pressure from domestic audiences to do something about opponents' policies and, as a result, choose to show competence and leadership in foreign affairs by announcing sanctions (Whang 2011; McLean and Whang 2014; McLean and Roblyer 2017). 


\section{RESEARCH DESIGN, DATA AND METHODS}

Measuring uncertainty is not a trivial task. If the source of uncertainty is private information about capabilities, resolve, or intentions, for instance, then by definition, such characteristics of a given state are unobservable to opponents or outside observers. Even though in some cases scholars were able to identify ex post specific sources of private information such as secret alliances, which later became public (Bas and Schub 2016b), identifying uncertainty systematically for all sources of private information remains infeasible. This, coupled with the fact that there are multiple potential sources of uncertainty that might be relevant for a given dispute, makes it difficult to differentiate various types of uncertainty from each other and isolate their individual effects on conflict in a large-N analysis with available data sources and existing methods.

Instead, this article pursues a more modest goal. For the liberal and realist factors that we identified in the previous section, our tests will estimate their aggregate, rather than individual, effects on the amount of uncertainty relevant to militarized disputes or sanction episodes. To this end, we employ a heteroskedastic probit (HP) model (Alvarez and Brehm 1995; 2002). Unlike ordinary probit, HP allows variance of the dependent variable to change across observations as a function of regressors. ${ }^{6}$ We will use the estimated variance that pertains to a given dyad as an indicator of the amount of uncertainty for that dyad for the specific outcome, whether it is militarized or non-militarized disputes, relative to other dyads in the sample. Thus, if a given regressor in the variance specification has a positive coefficient, we will interpret it as a factor that increases the amount of uncertainty for that specific outcome variable.

To test the hypotheses derived in the previous section, we combine two data sets: the first is Militarized Interstate Disputes (MIDs) data set (Ghosn, Palmer, and Bremer 2004), and the second is Threat and Imposition of Sanctions (TIES)

${ }^{6}$ Since the theories discussed in the previous section are agnostic about conflict initiation, the choice of HP and non-directed dyad years as the unit of analysis is appropriate for our empirical tests. For methods that analyze sequential strategic behavior using directed dyads, see Signorino (1999), Bas et al. (2008) and Bas (2012).

7 We model uncertainty as a function of explanatory variables in the variance term of our empirical model. The explanatory variables are drawn from realist and liberal schools in international relations. Note that the amount of uncertainty is embedded in our empirical models in the form of a variance term, which is fixed to one in canonical probit models but becomes a parameter to be estimated in our tests. The empirical models use the incidence of disputes or sanctions as dependent variables, which are determined in part by uncertainty, i.e., the variance parameter, which is determined by the realist and liberal variables. 
data set (Morgan, Bapat, and Krustev 2009). ${ }^{8}$ Our unit of observation is nondirected dyad-year ranging from 1816 to 2007 for militarized disputes, and from 1970 to 2000 for sanctions.

We use four dependent variables - two for conflict and two for economic sanctions. Military is a dummy variable that indicates a militarized dispute onset between two states in a given year. More specifically, the variable takes the value of one for the MIDs hostility level of 4 or 5 , indicating a use of force, and zero otherwise. Similarly, Dispute is a dichotomous variable indicating dispute onset between two states: the variable takes the value of one for MIDs hostility levels of greater than $\mathrm{o}$, and zero otherwise. For sanctions data, we use a dummy variable that captures the initiation of sanctions: Sanctions is coded as one if economic sanctions are imposed within a dyad in a given year, and zero otherwise. Finally, Sanction Threats is a binary indicator, which takes the value of one if a sanction threat was issued within a dyad in a given year, and zero otherwise.

To model the likelihood of disputes that involve the use of military and economic instruments, as well as varying levels of uncertainty that exist in different types of crisis interactions, we employ a list of variables that operationalize concepts central to realist and liberal approaches discussed in the previous section. The set of variables linked to realist hypotheses includes the dyadic capability ratio (Capability Ratio), which is calculated as the ratio of the weakest state's capabilities to the total capability of the dyad. This variable ranges from o for a completely asymmetric dyad to 5 representing a dyad at parity. States' capabilities are represented by their Composite Index of National Capability (CINC) scores (Singer et al. 1972). Capability Ratio is an appropriate measure of states' relative power due to the non-directed nature of our data. To test if uncertainty changes significantly during times of power shifts within a dyad, we also include a power transition variable (Power Transition), which measures the yearly change in the difference between the two states' capabilities, as a share of the total capability of the dyad. ${ }^{9}$ In the variance specification, we include No. of Great Powers to control for effects of international system polarity, represented by the number of great powers in the international system.

To test hypotheses derived from liberal approaches, we include variables that represent the Kantian peace tripod. First, Joint Democracy is a dichotomous variable that indicates a dyad with two democratic states (Polity scores of 7 or above). This variable has been extensively used in the literature to test the

\footnotetext{
8 The TIES data are available at http://www.unc.edu/ bapat/TIES.htm

9 In other words, if we define the two states' capabilities as cap_1 and cap_2, Power Transition shows the annual difference in cap.diff $=$ abs $\left(\right.$ cap $\left.\_1-c a p \_2\right) /($ cap_1 + cap_2 $)$.
} 
democratic peace theory. Second, we use Trade, which measures the total amount of trade between the two states in the dyad (logged). Finally, we include Joint IO membership, which counts the number of international governmental organizations that the two states are jointly members of. Note that Russett and Oneal $(2001,170)$ point out that a count variable is a necessary starting point but ultimately unrealistic. When using an aggregate count of IO memberships, the researcher is forced to assume that all IOs are essentially identical in their effect on the dependent variable. We address this concern by using weights: smaller IOs should provide more opportunities for closer interactions among member states, thereby facilitating more significant information exchange, and hence should contribute more to the reduction of uncertainty. Therefore, the measure assigns a larger weight to joint memberships in smaller IOs.

In addition, our analyses include a set of control variables based on the factors identified in the existing research as important determinants of international disputes. Alliance is a dummy variable that indicates the existence of an official alliance (defense pact, neutrality agreement, or entente). Rivalry captures the existence of an ongoing rivalry between the two states within a dyad: rival states are more likely to be involved in conflicts. We use Thompson's measure of rivalries to avoid endogeneity concerns with the likelihood of conflict (Thompson 2001). Contiguity is a 6-level ordinal variable that measures the level of territorial contiguity between the two states, ranging from direct land contiguity (1) to being separated by more than 400 miles of water (6). ${ }^{10}$ To control for states' interest similarity, we include $S$-Score that measures dyadic alliance portfolio similarity. Finally, to account for duration dependence, we also include Peace Years polynomials in each regression up to the third-degree polynomial, as suggested by Carter and Signorino (2010).

\section{RESULTS}

Tables 1 and 2 report our results for conflict models. The dependent variable in Table 1 is Military (militarized dispute initiation), indicating a militarized dispute onset, whereas Table 2 is based on a more general dispute initiation measure (Dispute) as the dependent variable. The first column of each table

\footnotetext{
${ }^{10}$ While the contiguity variable seems to fit with the offense-defense theory-a realist theory of war-and Mearsheimer's offensive realism that posits "stopping power of water," we focus narrowly on Waltz's neoclassical realism for our realist variables. We thank an anonymous reviewer for drawing attention to the alternative theoretical approaches.
} 
utilizes variables in the variance specification that are required for testing realist hypotheses regarding uncertainty levels, as well as a standard set of control variables in the main equation based on findings in previous research on interstate conflict. The second column of each table includes variables derived from liberal approaches in the variance specification and the same set of control variables in the main equation as in the first column. The third column reports results from a combined model that uses all the variables from the first two columns' variance specifications in modeling the uncertainty component.

Table 1. Militarized Dispute Onset and Uncertainty

\begin{tabular}{|c|c|c|c|}
\hline & Realist & Liberal & Combined \\
\hline \multicolumn{4}{|c|}{ Main Equation } \\
\hline \multirow[t]{2}{*}{ Capability Ratio } & $-1.08^{* *}$ & $-0.57^{* *}$ & -0.82 \\
\hline & 0.45 & 0.17 & 0.66 \\
\hline \multirow[t]{2}{*}{ Alliance } & 0.04 & 0.01 & 0.02 \\
\hline & 0.06 & 0.07 & 0.08 \\
\hline \multirow[t]{2}{*}{ Rivalry } & $0.93^{* *}$ & $0.84^{* *}$ & $0.93^{* *}$ \\
\hline & 0.07 & 0.07 & 0.1 \\
\hline \multirow[t]{2}{*}{ Contiguity } & $-0.25^{\star *}$ & $-0.21^{\star *}$ & $-0.23^{* *}$ \\
\hline & 0.01 & 0.01 & 0.02 \\
\hline \multirow[t]{2}{*}{ S-Score } & $-0.45^{* *}$ & $-0.48^{* *}$ & $-0.54^{* *}$ \\
\hline & 0.06 & 0.07 & 0.09 \\
\hline \multirow[t]{2}{*}{ Peace Years } & $-25.74^{* *}$ & $-30.78^{* *}$ & $-34.12^{\star *}$ \\
\hline & 2.06 & 2.86 & 3.73 \\
\hline \multirow[t]{2}{*}{ Peace Years squared } & $157.29^{* *}$ & $195.57^{* *}$ & $214.06^{* *}$ \\
\hline & 16.43 & 27.24 & 31.44 \\
\hline \multirow[t]{2}{*}{ Peace Years cubed } & $-250.75^{\star *}$ & $-332.83^{* *}$ & $-360.32^{* *}$ \\
\hline & 35.88 & 69.42 & 75.9 \\
\hline \multirow[t]{2}{*}{ Constant } & $-1.33^{* *}$ & $-1.20^{* *}$ & $-1.30^{* *}$ \\
\hline & 0.09 & 0.09 & 0.14 \\
\hline \multicolumn{4}{|c|}{ Variance Equation } \\
\hline \multirow[t]{2}{*}{ Capability Ratio } & $0.22^{*}$ & & 0.07 \\
\hline & 0.13 & & 0.2 \\
\hline \multirow[t]{2}{*}{ Power Transition } & 0.15 & & 0.11 \\
\hline & 0.16 & & 0.24 \\
\hline \multirow[t]{2}{*}{ No. of Great Powers } & $0.01^{* *}$ & & $0.02^{*}$ \\
\hline & 0.01 & & 0.01 \\
\hline \multirow[t]{2}{*}{ Joint Democracy } & & $-0.16^{\star *}$ & $-0.16^{\star *}$ \\
\hline & & 0.04 & 0.04 \\
\hline \multirow[t]{2}{*}{ Trade } & & $-0.06^{* *}$ & $-0.06^{* *}$ \\
\hline & & 0.02 & 0.02 \\
\hline \multirow[t]{2}{*}{ Joint IO Membership } & $0.07^{* *}$ & $0.07^{* *}$ & \\
\hline & & 0.02 & 0.02 \\
\hline Observations & 638,708 & 334,902 & 334,902 \\
\hline Log-likelihood & -3644.77 & -1873.52 & -1871.2 \\
\hline
\end{tabular}

Note: ${ }^{*} p\left\langle 0.10,{ }^{* *} p<0.05\right.$, Heteroskedastic Probit Model, $D V=$ Militarized Dispute Onset 
Table 2. Dispute Onset and Uncertainty

\begin{tabular}{|c|c|c|c|}
\hline & Realist & Liberal & Combined \\
\hline \multicolumn{4}{|c|}{ Main Equation } \\
\hline \multirow[t]{2}{*}{ Capability Ratio } & $-0.63^{* *}$ & $-0.26^{* *}$ & -0.42 \\
\hline & 0.23 & 0.08 & 0.39 \\
\hline \multirow[t]{2}{*}{ Alliance } & $0.28^{* *}$ & $0.15^{\star *}$ & $0.24^{* *}$ \\
\hline & 0.04 & 0.04 & 0.06 \\
\hline \multirow[t]{2}{*}{ Rivalry } & $1.42^{* *}$ & $1.04^{* *}$ & $1.36^{* *}$ \\
\hline & 0.06 & 0.04 & 0.08 \\
\hline \multirow[t]{2}{*}{ Contiguity } & $-0.30^{* *}$ & $-0.20^{* *}$ & $-0.26^{\star *}$ \\
\hline & 0.01 & 0.01 & 0.01 \\
\hline \multirow[t]{2}{*}{ S-Score } & $-1.23^{* *}$ & $-0.84^{* *}$ & $-1.14^{* *}$ \\
\hline & 0.04 & 0.03 & 0.06 \\
\hline \multirow[t]{2}{*}{ Peace Years } & $-27.67^{* *}$ & $-26.07^{* *}$ & $-34.89^{* *}$ \\
\hline & 1.61 & 1.95 & 2.64 \\
\hline \multirow[t]{2}{*}{ Peace Years Squared } & $111.98^{* *}$ & $130.42^{* *}$ & $173.66^{* *}$ \\
\hline & 11.62 & 18.65 & 23.62 \\
\hline \multirow[t]{2}{*}{ Peace Years Cubed } & $-116.92^{* *}$ & $-173.38^{* *}$ & $-231.15^{* *}$ \\
\hline & 17.89 & 38.83 & 48.97 \\
\hline \multirow[t]{2}{*}{ Constant } & $-0.44^{* *}$ & $-0.42^{* *}$ & $-0.53^{* *}$ \\
\hline & 0.06 & 0.05 & 0.09 \\
\hline \multicolumn{4}{|c|}{ Variance Equation } \\
\hline \multirow[t]{2}{*}{ Capability Ratio } & $0.21^{* *}$ & & 0.04 \\
\hline & 0.07 & & 0.12 \\
\hline \multirow[t]{2}{*}{ Power Transition } & -0.06 & & 0.08 \\
\hline & 0.08 & & 0.14 \\
\hline \multirow[t]{2}{*}{ No. of Great Powers } & $0.06^{* *}$ & & $0.05^{* *}$ \\
\hline & 0.00 & & 0.00 \\
\hline \multirow[t]{2}{*}{ Joint Democracy } & & $-0.19^{* *}$ & $-0.20^{* *}$ \\
\hline & & 0.02 & 0.02 \\
\hline \multirow[t]{2}{*}{ Trade } & & 0.01 & 0.00 \\
\hline & & 0.00 & 0.00 \\
\hline \multirow[t]{2}{*}{ Joint IO Membership } & & $0.12^{* *}$ & $0.12^{* *}$ \\
\hline & & 0.01 & 0.01 \\
\hline Observations & 638,708 & 334,902 & 334,902 \\
\hline Log-likelihood & -19574.72 & -8949.24 & -8891.83 \\
\hline
\end{tabular}

Note: ${ }^{*} p\left\langle 0.10,{ }^{* *} p<0.05\right.$, Heteroskedastic Probit Model, DV = Dispute Onset at any Hostility Level

With two exceptions, Capability Ratio is a significant predictor of dispute onset across all the models reported in Tables 1 and 2. Disputes and militarized conflicts are less likely in dyads with more equal distribution of capabilities, consistent with the balance of power literature, which predicts that parity in states' capabilities should reduce the probability of conflict. The variable fails to reach statistical significance in the combined models (Column 3) of Tables 1 and 2. We find that the existence of rivalry between two states is also a strong predictor for the emergence of disputes in all specifications provided in the 
tables. Similarly, states that are land contiguous and in general closer to each other are significantly more likely to be engaged in disputes than states that are separated by water. Alliance portfolio similarity between the two states of a given dyad appears to reduce the risk of disputes. At the same time, we find that existence of an alliance between the two states (such as a defense pact, neutrality agreement, or entente) does not significantly affect the likelihood of militarized conflict, while surprisingly increasing the likelihood of dispute onset, as Table 2 shows. ${ }^{11}$

Turning to the variance specifications, results suggest that interactions between states that are closer to parity in terms of their capabilities involve more uncertainty. This result emerges for both militarized conflicts and disputes more broadly defined, when only realist variables are included in the variance specification. When the realist and liberal variables are combined in Column 3 of Tables 1 and 2, Capability Ratio still has a positive coefficient but is no longer significant. Overall, this empirical result is supportive of Hypothesis M1, which anticipates a positive relationship between greater power parity at the dyadic level and levels of uncertainty. A similar, but more consistent result emerges with respect to the distribution of power at the system level. Hypothesis M2 states that the number of great powers at the system level should be positively associated with the amount of uncertainty. In both the realist and combined models reported in Tables 1 and 2, No. of Great Powers has a positive and significant coefficient, thereby lending empirical support to Hypothesis M2. Unlike the other two realist variables, Power Transition is insignificant as a predictor of uncertainty for both disputes and militarized conflicts (Columns 1 and 3 of Tables 1 and 2). Thus, predictions from the power transition theory with respect to the dynamic effect of shifts in capabilities on the amount of uncertainty, as summarized in Hypothesis M3, are not supported by empirical evidence.

The results provide mixed support for our hypotheses regarding the effects of liberal factors on uncertainty levels. Joint Democracy, as expected, consistently decreases the amount of uncertainty in militarized conflicts (Table 1) and disputes (Table 2), in the realist (Columns 1) and combined (Columns 3) models, consistent with Hypothesis M4. Although it is a weaker result, we also find that trade volumes decrease the amount of uncertainty in militarized conflicts in the liberal and combined specifications (Table 1), while this effect is not significant for disputes in general (Table 2). Finally, in contrast to Joint Democracy and

\footnotetext{
${ }^{11}$ We also find that all three peace duration polynomials are significant, indicating the existence of duration dependence as previous studies suggest.
} 
Trade, Joint IO Membership has a positive and statistically significant effect on the variance term for both disputes and conflict, in the liberal and combined specifications, contradicting Hypothesis M6. Sharing more IO memberships, weighted by the size of the IOs, tends to increase the amount of uncertainty. This surprising finding that goes against most of the literature on IOs' informational role needs further analysis, which we leave for future research.

Table 3. Economic Sanction Onset and Uncertainty

\begin{tabular}{|c|c|c|c|}
\hline & Realist & Liberal & Combined \\
\hline \multicolumn{4}{|c|}{ Main Equation } \\
\hline \multirow[t]{2}{*}{ Capability Ratio } & $0.58^{\star *}$ & 0.25 & $0.71^{* \star}$ \\
\hline & 0.16 & 0.17 & 0.2 \\
\hline \multirow[t]{2}{*}{ Alliance } & $0.20^{* *}$ & $0.38^{* *}$ & $0.22^{* *}$ \\
\hline & 0.06 & 0.16 & 0.11 \\
\hline \multirow[t]{2}{*}{ Rivalry } & -0.07 & 0.04 & 0.01 \\
\hline & 0.07 & 0.13 & 0.06 \\
\hline \multirow[t]{2}{*}{ Contiguity } & $-0.02^{* *}$ & $-0.06^{* *}$ & $-0.03^{* *}$ \\
\hline & 0.01 & 0.01 & 0.01 \\
\hline \multirow[t]{2}{*}{ S-Score } & -0.08 & $-0.23^{* *}$ & $-0.16^{* *}$ \\
\hline & 0.06 & 0.1 & 0.06 \\
\hline \multirow[t]{2}{*}{ Peace Years } & $5.43^{\star *}$ & $9.82^{\star *}$ & $5.36^{\star *}$ \\
\hline & 0.99 & 1.34 & 1.2 \\
\hline \multirow[t]{2}{*}{ Peace Years Squared } & $-9.87^{* *}$ & $-17.00^{* *}$ & $-9.62^{* *}$ \\
\hline & 1.94 & 4.7 & 2.15 \\
\hline \multirow[t]{2}{*}{ Peace Years Cubed } & $5.52^{* *}$ & $8.90^{* *}$ & $5.29^{* *}$ \\
\hline & 1.52 & 3.92 & 1.69 \\
\hline \multirow[t]{2}{*}{ Constant } & $-0.83^{* *}$ & $-1.21^{* *}$ & $-0.75^{\star *}$ \\
\hline & 0.21 & 0.17 & 0.23 \\
\hline \multicolumn{4}{|c|}{ Variance Equation } \\
\hline \multirow[t]{2}{*}{ Capability Ratio } & $-0.83^{* *}$ & & $-1.01^{* *}$ \\
\hline & 0.27 & & 0.37 \\
\hline \multirow[t]{2}{*}{ Power Transition } & 0.41 & & 0.28 \\
\hline & 0.69 & & 0.65 \\
\hline \multirow[t]{2}{*}{ No. of Great Powers } & $-0.07^{* *}$ & & $-0.07^{*}$ \\
\hline & 0.03 & & 0.04 \\
\hline \multirow[t]{2}{*}{ Joint Democracy } & & -0.07 & -0.04 \\
\hline & & 0.09 & 0.09 \\
\hline \multirow[t]{2}{*}{ Trade } & & -0.02 & -0.01 \\
\hline & & 0.01 & 0.01 \\
\hline \multirow[t]{2}{*}{ Joint IO Membership } & & 0.09 & 0.10 \\
\hline & & 0.15 & 0.15 \\
\hline Observations & 4,970 & 4,562 & 4,562 \\
\hline Log-likelihood & -1627.92 & -1496.36 & -1484.22 \\
\hline
\end{tabular}

Note: ${ }^{*} p<0.10,{ }^{* *} p<0.05$, Heteroskedastic Probit Model, DV = Economic Sanction Onset 
Table 4. Sanction Threats and Uncertainty

\begin{tabular}{|c|c|c|c|}
\hline & Realist & Liberal & Combined \\
\hline \multicolumn{4}{|c|}{ Main Equation } \\
\hline \multirow[t]{2}{*}{ Capability Ratio } & $-1.74^{\star *}$ & $-1.17^{*}$ & $-1.02^{* *}$ \\
\hline & 0.6 & 0.61 & 0.49 \\
\hline \multirow[t]{2}{*}{ Alliance } & 0.34 & 0.12 & 0.1 \\
\hline & 0.25 & 0.26 & 0.19 \\
\hline \multirow[t]{2}{*}{ Rivalry } & 0.02 & 0.07 & 0.06 \\
\hline & 0.2 & 0.26 & 0.22 \\
\hline \multirow[t]{2}{*}{ Contiguity } & 0.01 & 0.12 & 0.08 \\
\hline & 0.03 & 0.09 & 0.05 \\
\hline \multirow[t]{2}{*}{ S-Score } & -0.24 & -0.29 & -0.26 \\
\hline & 0.22 & 0.4 & 0.29 \\
\hline \multirow[t]{2}{*}{ Peace Years } & $14.03^{* *}$ & $17.14^{* *}$ & $12.16^{* *}$ \\
\hline & 2.77 & 2.11 & 2.19 \\
\hline \multirow[t]{2}{*}{ Peace Years Squared } & $-33.22^{\star *}$ & $-41.43^{* *}$ & $-29.18^{* *}$ \\
\hline & 6.32 & 6.47 & 5.68 \\
\hline \multirow[t]{2}{*}{ Peace Years Cubed } & $22.05^{\star *}$ & $27.75^{\star *}$ & $19.51^{* *}$ \\
\hline & 4.21 & 5.13 & 4.04 \\
\hline \multirow[t]{2}{*}{ Constant } & $-1.63^{* *}$ & $-2.49^{\star *}$ & $-1.74^{\star *}$ \\
\hline & 0.39 & 0.51 & 0.28 \\
\hline \multicolumn{4}{|c|}{ Variance Equation } \\
\hline \multirow[t]{2}{*}{ Capability Ratio } & $0.65^{*}$ & & 0.18 \\
\hline & 0.37 & & 0.34 \\
\hline \multirow[t]{2}{*}{ Power Transition } & -0.26 & & -0.66 \\
\hline & 0.42 & & 0.52 \\
\hline \multirow[t]{2}{*}{ No. of Great Powers } & -0.02 & & -0.06 \\
\hline & 0.05 & & 0.04 \\
\hline \multirow[t]{2}{*}{ Joint Democracy } & & -0.05 & -0.02 \\
\hline & & 0.1 & 0.09 \\
\hline \multirow[t]{2}{*}{ Trade } & & 0.01 & 0.01 \\
\hline & & 0.01 & 0.01 \\
\hline \multirow[t]{2}{*}{ Joint IO Membership } & & 0.11 & 0.10 \\
\hline & & 0.08 & 0.08 \\
\hline Observations & 4,970 & 4,562 & 4,562 \\
\hline Log-likelihood & -1073.87 & -985.6 & -982.55 \\
\hline
\end{tabular}

Note: ${ }^{*} \mathrm{p}\left\langle 0.10,{ }^{* *} \mathrm{p}\langle 0.05\right.$, Heteroskedastic Probit Model, DV = Economic Sanction Threats

Tables 3 and 4 report our results for models of economic sanctions. The dependent variable in Table 3 is Sanctions, a dummy variable that indicates the onset of economic sanctions, whereas Table 4 uses the initiation of sanction threats (Sanction Threats) as the dependent variable.

Model specifications in these two tables are identical to those reported in Tables 1 and 2 to allow for meaningful comparisons between realist, liberal, and combined approaches and between main and variance equations in the context 
of military and economic coercion. In addition, this approach enables us to address the question of whether the two coercive instruments are foreign policy complements or substitutes.

In Table 3, we find that Capability Ratio is positively and significantly associated with the onset of sanctions in the main equation of the realist and combined specifications. Moreover, in these models, Capability Ratio decreases uncertainty, as indicated by the negative and significant coefficients in the variance equation. This implies that as dyads reach a more equal distribution of capabilities, uncertainty tends to decrease and economic sanctions become more likely, which is consistent with Hypothesis SS1, and not Hypothesis SC1. Moreover, No. of Great Powers is also negatively and significantly associated with uncertainty during sanction episodes in the realist and combined models in Table 3. Thus, as the number of major powers in the system increases, uncertainty increases for militarized disputes (Table 1) but decreases for sanctions (Table 3). This result lends support to Hypothesis SS2, rather than Hypothesis $\mathrm{SC} 2$.

Taken together with our results from conflict models, these findings suggest that sanctions may be viewed as an alternative to military options, which is consistent with the argument that military and economic instruments serve as foreign policy substitutes. In high uncertainty environments, when conflict could be perceived as too risky or costly, sanctions can be regarded a safer, less uncertain alternative. When a given dyad is closer to parity, for instance, our models suggest that states find disputes, or escalation to militarized conflict to be associated with more uncertainty, and tend to refrain from these options, as indicated by the positive coefficient on Capability Ratio in the variance specification and the negative coefficient in the main equation. Yet, the same factor reduces uncertainty associated with sanction use and results in a higher likelihood of sanctions initiation. Similar effects operate at the system level with respect to the distribution of capabilities among major states. As the number of great powers increases, states experience higher uncertainty levels in situations of military coercion. At the same time, this factor reduces the amount of uncertainty with respect to sanctions initiation (the effect is not significant for sanction threats). ${ }^{12}$

Interestingly, we do not find evidence of a substitution effect in our liberal specifications: this is due to the fact that the three liberal variables do not have significant effects on uncertainty in our sanctions models. These variables fail to

12 It is worth noting that we do not test the substitution effect in a unified model of militarized disputes and sanctions. Therefore, we draw our conclusions with this limitation in mind. 
pass the conventional threshold of statistical significance in variance equations of both Tables 3 and 4 . The non-findings are surprising because joint democracy, trade, and shared IO membership are expected to increase state interactions and, hence, reduce uncertainty when states consider sanction initiation. Given that we also find that joint IO membership is associated with greater uncertainty in the case of disputes and conflict (Tables 1 and 2), our empirical analyses raise questions regarding IOs' actual effect on uncertainty in international crises. Previous studies point out that IOs' central functions are to provide information to member states, facilitate learning, and make monitoring and enforcement less costly and more efficient. Yet, our results appear to undermine the conventional wisdom and call for more future research into causal links between IO membership and uncertainty.

\section{CONCLUSION}

In this article, we focused on factors that affect levels of uncertainty in interstate disputes and economic sanctions. We formulated and tested a range of hypotheses based on established international relations theories that link power distribution, power transition, regime type, economic interdependence, and membership in international organizations with militarized and nonmilitarized dispute onset. We found that multipolar systems and dyadic power parity are positively and significantly associated with the amount of uncertainty, as realist approaches indicate, although we did not find any evidence of greater uncertainty levels when power transitions take place. Consistently with liberal theories, our tests showed that joint democracy and trade decreased uncertainty in interstate disputes.

While existing studies predominantly choose to focus on the use of either military or economic options, but not both, we show that analyzing the two types of foreign policies side by side can yield important and thought-provoking insights. Specifically, we found some evidence of a substitution effect: factors that increase the amount of uncertainty and the likelihood of disputes and militarized conflict can have opposite effects in sanctions episodes. This effect stems from the balance of capabilities at the dyadic and systemic levels. While our results serve as the first step in studying this relationship, they point to a promising direction for future research on the interdependence between economic and military policy options in states' decision-making during international crises. Finally, this article contributes to the growing empirical literature on sources of uncertainty in international relations, which lags behind 
the vast theoretical research on this topic.

\section{REFERENCES}

Abbott, Kenneth W. and Duncan Snidal. 1998. "Why States Act Through Formal International Organizations." Journal of Conflict Resolution $42(1), 3-32$.

Alvarez, Michael and John Brehm. 1995. "American Ambivalence Towards Abortion Policy: Development of a Heteroskedastic Probit Model of Competing Values." American Journal of Political Science 39(4), 10551082. . 2002. Hard Choices, Easy Answers. Princeton, NJ: Princeton University Press.

Arena, Philip and Scott Wolford. 2012. "Arms, Intelligence, and War." International Studies Quarterly 56(2), 351-365.

Arena, Philip. 2013. "Costly Signaling, Resolve, and Martial Effectiveness." Working paper.

Axelrod, Robert. 1981. "The Emergence of Cooperation among Egoists." American Political Science Review 75(2), 306-318.

Bas, Muhammet A. 2012. "Measuring Uncertainty in International Relations: Heteroskedastic Strategic Models." Conflict Management and Peace Science 29(5), 490-520.

Bas, Muhammet A. and Robert J. Schub. 2016a. "How Uncertainty about War Outcomes Affects War Onset." Journal of Conflict Resolution 6o(6), 1099-1128.

. 2016b. "Mutual Optimism as a Cause of Conflict: Secret Alliances and Conflict Onset." International Studies Quarterly 6o(3), 552-564.

. 2017a. "Peaceful Uncertainty: When Power Shocks Do Not Create Commitment Problems." Forthcoming at International Studies Quarterly.

. 2017b. "Theoretical and Empirical Approaches to Uncertainty and Conflict in International Relations." Working Paper.

Bas, Muhammet A., Curtis S Signorino, and Robert W Walker. 2008. "Statistical Backwards Induction: A Simple Method for Estimating Recursive Strategic Models." Political Analysis 16(1), 21-40.

Bas, Muhammet A, Curtis S Signorino, and Taehee Whang. 2014. "Knowing Ones Future Preferences: A Correlated Agent Model with Bayesian Updating." Journal of Theoretical Politics 26(1), 3-34. 
Blainey, Geoffrey. 1988. The Causes of War. London: Macmillan.

Boehmer, Charles, Erik Gartzke, and Timothy Nordstrom. 2004. "Do Intergovernmental Organizations Promote Peace?" World Politics 57(1), 1-38.

Carter, David and Curt Signorino. 2010. "Back to the Future: Modeling Time Dependence in Binary Data.” Political Analysis 18(3), 271-292.

Christensen, Thomas J., and Jack Snyder. 1990. "Chain gangs and passed bucks: Predicting alliance patterns in multipolarity." International Organization 44(2), 137-168.

Dorussen, Han and Hugh Ward. 2008. "Intergovernmental Organizations and the Kantian Peace." The Journal of Conflict Resolution 52(2), 189-212.

Fearon, James D. 1994. "Domestic Political Audiences and the Escalation of International Disputes.” American Political Science Review 88(3), 577592.

. 1995. "Rationalist Explanations for War." International Organization 49(3), 379-414.

Fortna, Virginia Page. 2003. "Scraps of Paper? Agreements and the Durability of Peace." International Organization 57(2), 337-372.

Gartzke, Erik, Quan Li, and Charles Boehmer. 2001. "Investing in the peace: Economic interdependence and international conflict." International organization 55(2), 391-438.

Ghosn, Faten, Glenn Palmer and Stuart Bremer. 2004. "The MID3 Data Set, 1993-2001: Procedures, Coding Rules, and Description." Conflict Management and Peace Science 21(2), 133-154.

Gilpin, Robert. 1983. War and Change in World Politics. Cambridge, UK: Cambridge University Press.

Grieco, Joseph M. 1988. "Anarchy and the Limits of Cooperation: A Realist Critique of the Newest Liberal Institutionalism." International Organization 42(3), 485-507.

Hafner-Burton, Emilie M. and Alexander H. Montgomery. 2008a. "Power or Plenty: How Do International Trade Institutions Affect Economic Sanctions?" Journal of Conflict Resolution 52(2), 213-242. . 2008b. "The Hegemon's Purse: No Economic Peace Between Democracies." Journal of Peace Research 45(1), 111-120.

Helms, Jesse. 1999. "What Sanctions Epidemic? U.S. Business' Curious Crusade." Foreign Affairs 78(1), 2-8

Ikenberry, G. John. 2001. After Victory: Institutions, Strategic Restraint, and the Rebuilding of Order After Major Wars. Princeton, NJ: Princeton University Press. 
Jervis, Robert. 1976. Perception and Misperception in International Politics. Princeton, NJ: Princeton University Press.

Keohane, Robert O. 1984. After Hegemony: Cooperation and Discord in the World Political Economy. Princeton, NJ: Princeton University Press.

Keohane, Robert O. and Lisa Martin. 1995. "The Promise of Institutionalist Theory.” International Security 20(1), 39-51.

Kugler, Jacek and Abramo FK Organski. 1989. "The power transition: A retrospective and Prospective Evaluation." Handbook of War Studies, 171-194.

Kydd, Andrew H. 1997. "Game Theory and the Spiral Model." World Politics 49(3), 371-400. . 2005. Trust and Mistrust in International Relations. Princeton, NJ: Princeton University Press.

Lake, David and Robert Powell. 1999. Strategic Choice and International Relations. Princeton, NJ: Princeton University Press

Lektzian, David and Mark Souva. 2003. "The Economic Peace between Democracies: Economic Sanctions and Domestic Institutions." Journal of Peace Research 40(6), 641-659.

Martin, Lisa and Beth Simmons. 1998. "Theories and Empirical Studies of International Institutions.” International Organization 52(4), 729-757

McLean, Elena and Dwight Roblyer. 2017. "Public Support for Economic Sanctions: An Experimental Analysis." Foreign Policy Analysis 13(1), 233-254.

McLean, Elena and Taehee Whang. 2014. "Designing Foreign Policy: Voters, Special Interest Groups, and Economic Sanctions." Journal of Peace Research 51(5), 589-602.

Mearsheimer, John J. 1994. "The False Promise of International Institutions." International Security 19(3), 5-49.

Moravcsik, Andrew. 1999. "A New Statecraft? Supranational Entrepreneurs and International Cooperation." International Organization 53(2), 267-306.

. 2000. "The Origins of Human Rights Regimes." International Organization 54(2), 217-252.

Morgan, T. Clifton, Navin Bapat, and Valentin Krustev. 2009. "The Threat and Imposition of Economic Sanctions, 1971-200o.” Conflict Management and Peace Science 26(1), 92-110.

Oneal, John R. and Bruce M. Russett. 1997. "The Classical Liberals Were Right: Democracy, Interdependence, and Conflict, 1950-1985." International Organization 41(2), 267-295. 
. 1999. "The Kantian Peace: The Pacific Benefits of Democracy, Interdependence, and International Organization.” World Politics $52(1), 1-37$.

. 2005. "Rule of Three, Let It Be: When More Is Better." Conflict Management and Peace Science 22(4), 293-310.

Organski, Alfred FK. 1968. World Politics. Alfred A. Knopf, New York.

Organski, A. F. and Jacek, Kugler. 1980. The War Ledger. Chicago, IL: Chicago University Press.

Powell, Robert. 1999. In the Shadow of Power: States and Strategies in International Politics. Princeton, NJ: Princeton University Press.

Reed, William. 2003. "Information, Power, and War." American Political Science Review 97(4), 633-641.

Russett, Bruce and John R. Oneal. 2001. Triangulating Peace: Democracy, Interdependence, and International Organizations. New York: Norton.

Schultz, Kenneth A. 1998. "Domestic Opposition and Signaling in International Crises." The American Political Science Review 92(4), 829-844.

. 1999. "Do Democratic Institutions Constrain or Inform? Contrasting Two Institutional Perspectives on Democracy and War." International Organization 53(2), 233-266.

Selden, Zachary. 1999. Economic Sanctions as Instruments of American Foreign Policy. New York: Praeger Publishers.

Signorino, Curtis S. 1999. "Strategic Interaction and the Statistical Analysis of International Conflict.” American Political Science Review 93(2), 27997.

Singer, J. David, Stuart Bremer, and John Stuckey. 1972. "Capability Distribution, Uncertainty, and Major Power War, 1820-1965.” In Bruce Russett eds., Peace, War, and Numbers. Beverly Hills, CA: Sage

Smith, Alastair and Allan C. Stam. 2004. "Bargaining and the Nature of War." Journal of Conflict Resolution 48(6), 783-813.

Spaniel, William and Peter Bils. Forthcoming. "Slow to Learn Bargaining, Uncertainty, and the Calculus of Conquest." Journal of Conflict Resolution.

Thompson, William R. 2001. "Identifying Rivals and Rivalries in World Politics." International Studies Quarterly 45(4), 557-586.

Voeten, Erik. 2005. "The Political Origins of the UN Security Council's Ability to Legitimize the Use of Force." International Organization 59(3), 527557.

Wagner, R. Harrison. 1994. "Peace, War, and the Balance of Power.” American Political Science Review 88(3), 593-607. 
Waltz, Kenneth N. 1959. Man, the State, and War: A Theoretical Analysis. New York: Columbia University Press. . 1979. Theory of International Politics. Boston, MA: Addison-Wesley Publishing Company.

Weber, Katja. 1997. "Hierarchy Amidst Anarchy: A Transaction Costs Approach to International Security Cooperation." International Studies Quarterly 41(2), 321-340.

Whang, Taehee. 2011. "Playing to the Home Crowd? Symbolic Use of Sanctions by the United States." International Studies Quarterly 55(3), 787-801.

[Received May 30, 2017; Revised July 17, 2017; Accepted August 8, 2017] 